\title{
A147 IL-7-ACTIVATED T CELLS AND MONOCYTES DRIVE B CELL ACTIVATION IN PATIENTS WITH PRIMARY SJÖGREN'S SYNDROME
}

A Bikker, KMG van der Wurff-Jacobs, AA Kruize, RP Peters, JWJ Bijlsma, FPJG Lafeber, JAG van Roon UMC Utrecht, Department of Rheumatology \& Clinical Immunology, Utrecht, The Netherlands; a.bikker@umcutrecht.nl

\subsection{6/ard.2010.149005.14}

In primary Sjögren's syndrome (pSS) patients local T and B cell-driven inflammation can contribute to destruction of exocrine glands associated with clinical symptoms of dryness. Recently we documented increased interleukin 7 (IL-7) and IL7R expression in labial salivary glands of pSS patients. We have shown that IL-7 causes T cell-dependent monocyte activation. Although there are indications that IL-7 affects the activity of developing human B cells, the effect of IL-7 on mature $B$ cell activation in human autoimmune diseases has not been reported. Because $B$ cell activation plays a pivotal role in pSS pathology we investigated the capacity of IL-7 to induce $T$ cell-dependent $B$ cell activation.

Peripheral blood mononuclear cells (PBMCs) from pSS patients $(n=6)$ were cultured with and without IL-7. Furthermore, isolated CD4 T and CD19 B cells were co-cultured with and without IL-7 as well, and in the presence or absence of CD14 monocytes/macrophages $(n=6)$. Proliferation was measured using $3 \mathrm{H}$-thymidine incorporation and by Ki67 expression (FACS analysis). Ex vivo IL-7R expression and activation marker expression (HLA-DR, CD25) on CD4 $\mathrm{T}$ and $\mathrm{B}$ cells were measured by FACS analysis.

Nearly all CD4 T cells express the IL-7R $(93.6 \pm 1.4 \%)$, while $\mathrm{B} 3$ cells and monocytes do not. IL-7 increased proliferation of PBMC pSS (from 2000 to $13000 \mathrm{cpm}, \mathrm{p} \leq 0.001$ ), which was associated with significant increases in Ki67+CD4 $\mathrm{T}$ cells (from $2.7 \pm 0.4 \%$ to $13.8 \pm 4.0 \%$ ) and $\mathrm{Ki} 67+\mathrm{B}$ cells (from 1.5 $\pm 0.2 \%$ to $3.4 \pm 0.5 \%$ ). Additionally, IL-7 up regulated markers of activation on CD4 $\mathrm{T}$ cells (CD25+ CD4 $\mathrm{T}$ cells from $28.8 \pm 4.0 \%$ to $79.8 \pm 2.4 \%, p \leq 0.001$; HLA-DR+ T cells from $7.1 \pm 0.4 \%$ to $8.9 \pm 0.7 \%, p \leq 0.05$ ), and on B cells (HLA-DR MFI from $317 \pm 109$ to $421 \pm 129, \mathrm{p}<0.01$; mean increase $33 \%$ ). In CD4 $\mathrm{T}$ and $\mathrm{B}$ cell co-cultures, IL-7 activated $\mathrm{T}$ cells, but caused minimal B cell activation (MFI HLA-DR from 214 \pm 32 to $233 \pm 30, p \leq 0.05$; mean increase $8.8 \%$ ). As it has been shown that monocytes are able to support $B$ cell activation and can be stimulated by IL7-activated CD4 $\mathrm{T}$ cells, the capacity of monocytes to facilitate IL-7-induced B cell activation was examined. We report that indeed IL-7-induced T cell activation of $B$ cells is significantly enhanced by monocytes (MFI HLA-DR on B cells from $210 \pm 32$ to $284 \pm 53$, p $\leq 0.05$; mean increase $35 \%$ ).

Our results show that IL-7 activates B cells in a T cell-dependent manner which is facilitated by monocytes. Since increased IL-7 levels and monocyte/macrophage numbers are associated with increased immunopathology in pSS this suggests that IL-7-driven B cell activation might contribute to inflammation and tissue-destruction in pSS.

Funding This study was financially supported by the Dutch Arthritis Association ('het Nationaal Reumafonds'). 